УДК 616.361- 002.1 - 089

DOI 10.11603/2414-4533.2016.3.6790

() С. І. САВОЛЮК, В. О. ЛОСЄВ

Національна медична академія післядипломної освіти імені П. Л. Шупика мОз України Вінницький національний медичний університет ім. М. І. Пирогова

\title{
Прогнозування ризику неспроможності біліодигестивних анастомозів на основі побудови комплексної спектрофотометричної моделі стінки
} холедоха

\author{
S. I. SAVOLIUK, V. O. LOSIEV \\ Vinnytsia National M. Pyrohov Medical University P. Shupyk \\ National Medical University of Postgraduate Education
}

\section{PREDICTING THE RISK OF FAILURE OF BILIODIGESTIVE ANASMOMOSES BASED ON BUILDING OF INTEGRATED SPECTROPHOTOMETER MODEL OF CHOLEDOCHITIS WALL}

\begin{abstract}
У роботі проведено аналіз лікування 156 пацієнтів, яким було застосовано метод хірургічної корекції у формі створення біліодигестивних анастомозів в умовах гострого холангіту. Досліджували питання виникнення неспроможності створених біліодигестивних анастомозів у післяопераційному періоді. Було встановлено, що хронічний запальний процес стінки загальної жовчної протоки призводить до необоротних кількісних та якісних змін шарнірної структури колагенових волокон. Ступінь морфофункціональних змін колагенових волокон стінки загальної жовчної протоки корелює 3 ризиком виникнення неспроможності біліодигестивних анастомозів. Інтраопераційна діагностика гістооптичних змін колагенових волокон відбувалась за допомогою поляризаційної оптичної мікроскопії, яку визнано як експресметодику оцінки зазначених змін із подальшою побудовою моделі стінки холедоха та виконанням подальшої корекції операційного втручання залежно від результатів зазначених комплексних досліджень.

In scientific work the analysis of surgical treatment of 156 patients who underwent method of surgical correction by creation of bloghosting anastomosi in conditions of acute cholangitis. Acute cholangitis occurred as a complication of benign nosological forms of obstructive jaundice. Attention was given to the occurrence of an insolven cycreated by biliodigestive anastomoses in the postoperative period. It was found that chronic inflammation of the wall of the common bile duct leads to irreversible quantitative and qualitative changes of the hinge structure of the collagen fibers. The degree of morphofunctional changes of collagen fibers in the wall of the common bile duct is correlated with the risk of insolvency biliodigestive anastomoses. Intraoperative diagnosis gloating changes of collagen fibers occurred by using polarizing optical microscopy, which is recognised as an Express method for the assessment of the changes with subsequent model building of the wall of the common bile duct and performing further correction surgery depending on the results of the complex investigations.
\end{abstract}

Постановка проблеми і аналіз останніх досліджень та публікацій. Проблема лікування ЖКХ залишається однією $з$ актуальних у клінічній хірургії у зв’язку зі зростанням кількості пацієнтів 3 холедохолітіазом (14,6 \%) та ростом частоти ускладнень (3,23 \%) цього захворювання [1]. 3 переліку різноманітних ускладнень слід особливу увагу надати гострому холангіту (ГХ). ГХ хоча i $€$ невід'ємним патологічним елементом в ході обструкції жовчних проток, в останній час набув статусу самостійної хвороби [2] з розвитком біліарного сепсису. Летальність при гострому холангіті залишається високою і становить від 7 до 65 \% [3].

Важливим питанням біліарної хірургії $є$ вибір оптимального методу завершення холедохотомії. В цьому контексті питання визначення критеріїв оцінки та прогнозування перебігу післяоперацій- ного періоду при створенні біліодигестивних анастомозів (БДА) у хворих з ускладненнями холедохолітіазу в умовах ГХ залишається відкритим [2].

Мета роботи: покращити результати хірургічного лікування хворих 3 холедохолітіазом, що ускладнений ГХ, шляхом проведення аналізу структурно-функціональних змін стінки холедоха на основі кількісних показників методу поляризаційної мікроскопії для прогнозування неспроможності анастомозу.

Матеріали і методи. В основу дослідження покладено аналіз результатів лікування 156 хворих на холедохолітіаз, що ускладнений ГХ, за період з 2010 до 2015 р. на базі клініки кафедри хірургії № 2 Вінницького національного медичного університету ім. М. І. Пирогова. 
Критерії включення хворих у дослідження:1) холедохолітіаз із множинними конкрементами; 2) холедохолітіаз із наявністю поодинокого, великих розмірів (більше 2 см), конкремента в позапечінкових жовчних шляхах, що міститься разом $з$ множинними дрібними конкрементами; 3) парапапілярні дивертикули; 4) наявність операційних втручань у минулому на верхньому поверсі черевної порожнини; 5) невдалі спроби попередньої ендоскопічної літоекстракції.

Середній вік хворих становив $(67,1 \pm 1,23)$ року (min - 44 роки, max - 84 роки), із них жінок було 117 (75 \%), чоловіків - 78 (25 \%).

Структура основних захворювань, ускладненням яких був гострий холангіт: ЖКХ з гострим калькульозним холециститом - 30 хворих, ЖКХ із хронічним калькульозним холециститом - 41, ПХЕС - 85 .

Супутня патологія виявлена в 145 хворих. У структурі супутньої патології на першому місці IXC - 64 хворих, гіпертонічна хвороба - 34, ХОЗЛ - 12, вентральні грижі передньої черевної стінки - 15, цукровий діабет - 14, варикозна хвороба вен нижніх кінцівок - 16, ожиріння 2-4 ст. - 12, захворювання опорно-рухового апарату -2 .

Хворим за весь період стаціонарного лікування проводили комплексну терапію згідно з наказом № 297 від 02.04.2010 МОЗ України.

Хворим, які підлягали операційному лікуванню, проводили комплексну консервативну терапію у формах передопераційної підготовки з антибактеріальною та протизапальною терапією у передопераційний період для зменшення ступеня ендотоксикозу [4].

Оцінку тяжкості хворих на ГХ проводили згідно з критеріями С. Ф. Багненко: 49 хворих з легким перебігом, 64 - із середнім ступенем тяжкості, 43 - із тяжким перебігом ГХ.

Оцінку рівня ендогенної інтоксикації проводили шляхом комплексної оцінки об’єктивних даних та результатів лабораторних досліджень (Н. Яблучанський, 1983) та інтегрального показника тяжкості (М. М. Соловйов, 2000 р.) [4].

Під час операційного втручання з лапаротомного доступу мобілізували холедох. Виконували холедохотомію, під час проведення якої проводили біопсію його стінки. Отримані в результаті біопсії мікропрепарати фіксували у 10 \% розчині нейтрального формаліну, потім зневоднювали у спиртах по висхідній концентрації, здійснювали заливку до парафінових блоків, виготовляли гіс-

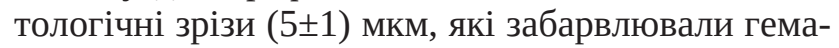
токсиліном за ван Гізон, Массону, толуоїдиновим синім при рН 2,6 та 5,3, проводили ШИК-реакцію, гістологічну експрес-оцінку за допомогою поляризаційного мікроскопічного дослідження з використанням інтерференційно-поляризаційного мікроскопа МП-1.

3156 хворих 48 виконано створення ХДА за різними методиками, 64 пацієнтам створено XЄА, 44 хворим застосовано комбіноване зовнішньовнутрішнє дренування. Різні види методик ХДА поділено таким чином: ХДА за методикою Кіршнера - 9 хворих, ХДА за методикою Фінстерера 14, ХДА за методикою Юраша у модифікації Віноградова - 2 хворих, ХДА за методикою Юраша -23 хворих.

У післяопераційному періоді основна мета моніторингу була спрямована на діагностику ранніх ускладнень у формі неспроможності БДА.

Статистичну обробку отриманих результатів проводили за допомогою статистичного пакета SPSS-13.

Результати досліджень та їх обговорення. У результаті проведеного лікування було виділено три групи пацієнтів. Перша група хворих $(\mathrm{n}=62)$ зі сприятливим клінічним виходом, в яких сформований БДА був спроможний. Другу групу (n=81) склали пацієнти із середнім ризиком виникнення неспроможності. 3 метою запобігання виникненню ознак неспроможності під час операційного втручання ми використовували додаткові методи захисту створеного анастомозу. Третю групу $(\mathrm{n}=13)$ склали пацієнти з високим ризиком виникнення неспроможності, в наведених випадках ми утримувалися від формування БДА.

Морфологічне дослідження біоптатів стінки холедоха полягало в побудові спектрометричної моделі стінки останнього. У всіх мікропрепаратах стінки виявлено наявність колагенових волокон. За допомогою спектрального аналізу виявлено наявність таких типів колагену: 1, 1А, 1Б, 2 та 3. Різниця морфологічної структури стінки полягала у співвідношенні названих типів між собою.

Наявність переважного типу в одному дослідному біопсійному препараті у відсотковому співвідношенні більше 51 \% трактувалась нами як абсолютне переважання зазначеного типу.

У першій клінічній групі було 62 макропрепарати, де абсолютну більшість займав 1 тип колагену. В 42 біопсійних препаратах 1 тип колагену склав 75 \%, у 12 - 68 \%, у 10 зразках - 55 \%. В цій дослідній підгрупі виявлено ще колаген 1 А типу. Останній разом із 1 типом не становив великих розбіжностей.

Наявність у стінці холедоха, за даними фотоспектрального аналізу, типів колагену 1 та $1 \mathrm{~A}$ 
свідчила, на нашу думку, про зрілість та міцність структурного колагену та можливість процесу оборотності патологічних змін стінки холедоха, які спричинені запальною альтерацією та ексудацією в умовах ГХ.

Морфологічне дослідження біптатів вказувало тільки на помірний набряк у власній пластинці слизової оболонки. Колагенові волокна тонкі та звивисті, з орієнтацією волокон у паралельному напрямку, проявляли високий ступінь анізотропії, дихроїзм останніх чітко простежували.

Типи 1 та 1 А проявляли всі біохімічні та гістологічні критерії сформованості власних волокон, топоізометричної будови фібрилярної структури колагену, позитивні критерії зрілості, будови міжхімічних зв’язків та здатності до правильного зчитування інформації про будову наступних колагенових ланцюгів під час процесу преколагенування та активну задіяність у процесах посттрансляційної модифікації на етапах утворення потрійної спіралі матричного колагену. Колаген у таких хворих зберігав здатність до багатоетапного процесу синтезу преколагену, посттрансляційної модифікації та утворення потрійної спіральної структури колагенового волокна, поява якої є запорукою функціональної здатності та активності зрілих матричношарних форм, можливості в подальшому відтворювати потрійну структуру колагену.

Наявність вищезазначених типів колагену давала змогу трактувати патологічні зміни в стінці холедоха як ті, що не можуть структурними шляхами впливати на функціональну здатність колагену. Існування патологічних змін у стінці холедоха не здатне призводити до суттєвих змін в процесах нормального функціонування колагенових волокон. Колаген у таких умовах зберігає здатність до виконання тих функцій у стінці холедоха, що притаманні в нормальних умовах.

Враховуючи все вищезазначене, хворих $з$ типами 1 та 1А колагенових волокон ми відносили до групи, в якій стінка холедоха зберігала свою структурну одноманітність та єдність, тим самим таким хворим можливе виконання різних видів внутрішнього дренування.

Другу клінічну групу хворих зі значною більшістю 1Б та 2 типів колагену, за результатами поляризаційного дослідження, трактували як групу помірних морфофункціональних змін стінки холедоха.

У наведеній клінічній групі був 81 макропрепарат, де абсолютну більшість посіли 1Б та 2 типи колагену. Ранжування відбулось таким чином: в 46 біоптатах - 1Б, 2 типи колагену склали $70 \%$, у 25 зразках - 65 \%, у 10 зразках - 55 \%.
У 2 групі пацієнтів, окрім судинних порушень, у стінці холедоха мали місце деструктивні зміни колагену власної пластинки слизової оболонки. Волокна мали вигляд гомогенної та рихлої структури без чітких меж. У підслизовій основі були наявні гігантські вогнища некрозу. Значна більшість колагенових волокон дезорієнтована, різко стоншена.

Під час поляризаційного дослідження патологічні зміни стінки холедоха призводили до граничного стану, коли наявний колаген був спроможний тільки виконувати функції каркасоутворення та володів здатністю до процесу регресування наявних функціональних змін у його топоізометричній структурі. Багатоетапні процеси синтезу преколагену, посттрансляційної модифікації та утворення потрійної спіральної структури були втрачені.

Наявність поряд з 1Б та 2 типами 1 та $1 \mathrm{~A}$ типів колагенового волокна дає здатність структурному колагену до оборотності патологічних змін.

Структурні зміни в матрично-шарній структуpi стінки холедоха дозволяли виконання цій групі різних видів внутрішнього дренування із застосуванням комплексу засобів для захисту сформованого БДА.

Під час комплексного поляризаційно-спектрометричного аналізу третьої групи стінка холодоха містила поряд з типами 1-2 у значній кількості 3 тип колагену. Наявність відсоткової більшості 3 типу в стінці холедоха трактувалась нами як така група, структурні зміни стінки холедоха якої досягли неприпустимого рівня, коли існуючий колаген повністю втратив здатність до утворення третинної структури та процеси ізомеризації відбуваються з неприпустимою кількістю помилок зчитування й трансляції білкової структури. У стінці холедоха хворих превалює за якісними властивостями молода форма колагену, яка $є$ незрілою і не проявляє здатності до процесів трансляції. Кількість молодої форми колагену вже на етапі виконання операційного втручання досягла критичних значень. У цих умовах утворення повноцінного колагену, дотримання стадійності в процесі дозрівання колагенового ланцюга $є$ неможливим.

Висновки. 3 метою визначення ризиків неспроможності БДА ми вважаємо за необхідне досліджувати спектральний розподіл типів колагену у відсоткових значеннях з наступною побудовою спектральної шкали типів колагенових волокон. Хворих, у яких в стінці холедоха переважали типи колагену 1 та $1 \mathrm{~A}$, ми відносили до групи з низьким ризиком виникнення неспроможності БДА. Групу хворих зі значною більшістю 1Б та 2 типів 
колагену трактували як групу помірних змін стінки холедоха. Хворих з переважанням 3 типу кола-

\section{СПИСОК ЛІТЕРАТУРИ}

1. Десятерик В. І. Діагностика та лікування гострих ускладнень жовчнокам'яної хвороби на тлі механічної жовтяниці / В. І. Десятерик, О. В. Котов, Є. С. Шевченко // Український журнал хірургії. - 2014. - № 1. - С. 140-143.

2. Ничитайло М. Ю. Гостра біліарна інфекція: оновлений погляд згідно 3 Токійськими клінічними рекомендаціями 2013 (TG 13) / М. Ю. Ничитайло, А. І. Гуцуляк, М. С. Загрійчук // Здоров’я України. Хірургія. Ортопедія. Травматологія : гену розглядали як групу високого ризику виникнення неспроможності БДА.

тематичний номер. - К., 2015. - № 2. - С. 12-13.

3. Казаков В. Н. Поляризационная микроскопия в биологии и медицине : монография / В. Н. Казаков, В. Г. Шлопов. - Донецк : Каштан, 2008. - 320 с.

4. Годлевський А. І. Діагностика та моніторинг ендотоксикозу у хірургічних хворих : монографія / А. І. Годлевський, С. І. Саволюк. - Вінниця : Нова Книга, 2015. - 232 с.

Отримано 04.05.16 